\section{Jurnal Mitra Pendidikan (JMP Online)}

URL : http://e-jurnalmitrapendidikan.com

\title{
PENINGKATAN HASIL BELAJAR PPKn \\ MELALUI PEMBELAJARAN ONLINE BERBASIS QUIZIZZ
}

\author{
Dionisius Heckie Puspoko Jati \\ Universitas Kristen Satya Wacana
}

INFORMASI ARTIKEL

Dikirim : 08 Mei 2020

Revisi pertama : 14 Mei 2020

Diterima : 29 Mei 2020

Tersedia online : 24 Juni 2020

Kata Kunci: Hasil Belajar, Pembelajaran Online Berbasis Quizizz.

Email: puspokojati@gmail.com
ABSTRAK

Penelitian ini bertujuan untuk mengetahui peningkatan hasil belajar peserta didik kelas VIII A SMP Kristen 2 Salatiga melalui penerapan model pembelajaran online berbasis aplikasi quizizz. Jenis penelitian ini adalah Penelitian Tindakan Kelas (PTK). Berdasarkan hasil penelitian, dapat disimpulkan bahwa penerapan model pembelajaran online berbasis aplikasi quizizz dapat meningkatkan hasil belajar aspek kognitif atau pengetahuan peserta didik. Sebelum diterapkan model pembelajaran online berbasis aplikasi quizizz nilai rata-rata kelas pada ranah kognitif 59,3 persentase ketuntasan 22,7\%,. Pada siklus I hasil belajar peserta didik yaitu rata-rata kelas pada ranah kognitif 76,3 dengan persentase ketuntasan 68,1. Pada siklus II hasil belajar peserta didik yaitu ratarata kelas pada ranah kognitif 88,5 dengan persentase ketuntasan 100\%. Berdasarkan hasil penelitian dan pembahasan, serta analisis data yang telah diuraikan dapat disimpulkan bahwa pembelajaran online dengan aplikasi quizizz dapat meningkatkan hasil belajar aspek kognitif atau pengetahuan PPKn kelas VII A SMP Kristen 2 Salatiga pada Semester Genap Tahun Pelajaran 2019/2020. 


\section{PENDAHULUAN \\ Latar Belakang}

Dalam upaya pencegahan perkembangan dan penyebaran Corona (Covid19) di lingkungan Satuan Pendidikan Kota Salatiga. Kepala Dinas Pendidikan Kota Salatiga mengirimkan Surat Edaran Nomor 420/1554/401, tertanggal 26 Maret 2020 tentang Pelaksanaan Kebijakan Layanan Pendidikan dalam masa darurat penyebaran Corona virus Disease (COVID-19) pada Satuan Pendidikan kota Salatiga ke setiap Satuan Pendidikan di Kota Salatiga. Berdasarkan hal tersebut, setiap Satuan Pendidikan Kota Salatiga wajib melaksanakannya. Beberapa sekolah menerapkan pemberian tugas-tugas setiap mata pelajaran dan akan dikumpulkan pada saat sekolah sudah masuk. Hal lain yang dilakukan sekolah, dengan memberikan soal atau tugas selanjutnya dikirimkan lewat WA (whatshaap) kepada gurunya.

Pemberian tugas kepada siswa tersebut kurang memenuhi kebutuhan siswa terhadap kontens atau konsep materi yang diharapkan untuk pencapaian kompetensi yang sudah ditetapkan. Berdasarkan wawancara dengan orang tua peserta didik dan guru, ditemukan beberapa temuan diantaranya peserta didik sebaliknya merasa terbebani karena setiap guru memberikan tugas dalam waktu bersamaan, dapat dibayangkan terdapat minimal 13 mata pelajaran yang keseluruhannya memberikan tugas secara serentak kepada siswa. Suatu hal yang sangat meresahkan adalah tugas-tugas yang diberikan guru tidak dibahas atau ditindaklanjuti, sebaliknya siswa dijejali dengan tugas baru lagi. Proses pembelajaran PPKn di kelas VIII A SMP Kristen 2 Salatiga mengalami hal yang sama jika dilaksanakan seperti sekolah-sekolah di atas. Banyak peserta didik yang berpendapat kehilangan waktu belajar yang seharusnya menjadi hak mereka untuk memperolehnya. Bukan hanya hak untuk belajar dan tatap muka di kelas tetapi jauh lebih penting adalah hak untuk diberi pelayanan terhadap ketidakmengertian mereka dari konsep materi yang tidak pahami.

Setelah peneliti melakukan observasi dan berkoordinasi dengan pihak sekolah, peneliti berkeinginan untuk melakukan perbaikan pembelajaran ini. Untuk mengatasi permasalahan yang muncul ini, peneliti mencoba melakukan pembelajaran dengan memanfaatkan teknologi komputer yang dewasa ini sudah banyak dikenal dan dimanfaatkan dalam dunia pendidikan. Perkembangan teknologi informasi dan komunikasi telah membawa perubahan yang sangat besar bagi kemajuan dunia pendidikan. Bentuk dari perkembangan teknologi informasi yang dikembangkan dalam dunia pendidikan adalah E-Learning.

E-Learning merupakan sebuah inovasi pembelajaran yang mempunyai konstribusi besar terhadap perubahan proses pembelajaran. Penggunaan $E$ Learning dalam proses belajar menuntut siswa lebih banyak melakukan aktivitas lain seperti mengamati, melakukan, dan mendemonstrasikan, dimana proses belajar tidak hanya lagi mendengarkan uraian materi dari guru. Salah satu aplikasi yang dapat digunakan sebagai media pembelajaran interaktif adalah Quizizz.

Penelitian tentang aplikasi e-Learning berbasis Quizizz pernah dilakukan oleh Leony Sanga Lamsari Purba (2019). Hasil penelitian telah menunjukkan bahwa e-Learning berbasis Quizizz berpengaruh terhadap hasil belajar siswa. Penelitian yang sama juga telah dilakukan oleh Ramadhan Prasetya Wibawa, dkk 
(2019) tentang penerapan media e-Learning berbasis Quizizz untuk meningkatkan aktifitas dan hasil belajar siswa. Hasil penelitian ini menunjukkan terjadi peningkatan aktifitas dan hasil belajar siswa yang menggunakan pembelajaran $e$ Learning berbasis Quizizz. Pembelajaran dengan menggunakan elearning Quizizz dapat membantu guru maupun peserta didik dalam proses pembelajaran.

E-Learning Quizizz membantu guru dalam membuka kesempatan komunikasi yang lebih luas kepada peserta didik untuk ikut berperan aktif dalam proses pembelajaran baik individu maupun kelompok. Quizizz dapat membantu peserta didik untuk memperdalam konsep materi yang diperoleh melalui pemberian tugas yang diberikan guru. Pembelajaran e-Learning Quizizz sangat membantu proses pembelajaran selama pencegahan virus Corona (Covid-19), siswa tetap bisa mengikuti pembelajaran walau berbekal jaringan internet sederhana, kapanpun, dan dimanapun mereka berada. Pembelajaran e-Learning Quizizz bertujuan untuk meningkatkan hasil belajar siswa kelas VIII A.

\section{Rumusan Masalah}

Rumusan Masalah dalam penelitian ini adalah bagaimanakah peningkatan hasil belajar peserta didik kelas VIII A SMP Kristen 2 Salatiga melalui penerapan model pembelajaran online berbasis quizizz?

\section{Tujuan Penelitian}

Tujuan Penelitian ini adalah mengetahui peningkatan hasil belajar peserta didik kelas VIII A SMP Kristen 2 Salatiga melalui penerapan model pembelajaran online berbasis quizizz.

\section{KAJIAN PUSTAKA \\ Pembelajaran e-Learning}

Pembelajaran e-Learning merupakan sebuah pembelajaran baru yang sering kali disebut dengan online learning atau pembelajaran online. Pembelajaran online dapat diartikan sebagai sebuah inovasi dalam pembelajaran. Menurut Fendi Rakman (2009:24) E-Learning merupakan bentuk pembelajaran/pelatihan jarak jauh yang memanfaatkan teknologi telekomunikasi dan informasi, misalnya internet, video/audio conferencing (secara langsung dan tidak langsung). Model pembelajaran e-Learning memiliki ciri-ciri khusus yang membedakan dengan pembelajaran lain umumnya.

Pembelajaran e-Learning menitikberatkan kegiatan pembelajaran dengan memanfaatkan internet dalam penyampaian materi pembelajaran dari guru kepada para peserta didik. Dengan menggunakan sarana internet pembelajaran pun akan terasa lebih modern dan lebih menyenangkan untuk dilakukan oleh peserta didik. Pembelajaran $e$-Learning, kegiatan yang berlangsung dapat terjadi kapan saja dan dimana saja tanpa batas waktu dan tempat, kondisi yang penting ada dalam pembelajaran e-Learning ini adalah ketersediaan alat dan tersedianya jaringan yang menghubungkan ke internet. Hal inilah yang menjadikan pembelajaran $e$ Learning sebagai sebuah pembelajaran yang efektif di zaman era globalisasi.

Perbedaan pembelajaran konvensional dengan e-Learning yaitu pada pembelajaran konvensioanal guru dianggap sebagai orang yang serba tahu dan 
ditugaskan untuk menyalurkan ilmu pengetahuan kepada peserta didiknya. Sedangkan di dalam e-Learning fokus utamanya adalah peserta didik. Peserta didik mandiri pada waktu tertentu dan bertanggung jawab untuk pembelajarannya. Suasana pembelajaran elearning akan memaksa peserta didik memainkan peranan yang lebih aktif dalam pembelajarannya. Pelajar membuat perancangan dan mencari materi dengan usaha, dan inisiatif sendiri.

\section{Aplikasi Pembelajaran e-Learning}

Salah satu aplikasi dalam pembelajaran e-Learning adalah Quizizz. Quizizz adalah aplikasi pendidikan berbasis game, yang membawa aktivitas multi pemain ke ruang kelas dan membuatnya di kelas latihan interaktif dan menyenangkan. Dengan menggunakan Quizizz, peserta didik dapat melakukan latihan di dalam kelas pada perangkat elektronik mereka. Tidak seperti itu aplikasi pendidikan lainnya, Quizizz memiliki karakteristik permainan seperti avatar, tema, meme, dan musik menghibur dalam proses pembelajaran. Quizizz juga memungkinkan peserta didik untuk saling bersaing dan memotivasi mereka belajar. Peserta didik mengambil kuis pada saat yang sama di kelas dan melihat peringkat langsung mereka di papan peringkat. Instruktur dapat pantau prosesnya dan unduh laporan ketika kuis selesai untuk mengevaluasi kinerja peserta didik. Menggunakan ini aplikasi membantu merangsang minat dan meningkatkan konsentrasi peserta didik. Selanjutnya, dengan meningkatnya konsentrasi peserta didik dalam pembelajaran maka akan meningkatkan hasil belajarnya. Hasil belajar merupakan tolak ukur pemahaman peserta didik yang melakukan tes yang sebelumnya telah melakukan suatu pembelajaran. Kunandar (2013: 62) menyatakan bahwa hasil belajar adalah kompetisi atau kemampuan tertentu baik, kognitif, afektif, maupun psikomotorik yang dicapai atau dikuasia peserta didik setelah mengikuti proses belajar mengajar. Hasil belajar merupakan pola-pola perbuatan, nilai-nilai, pengertian, sikap, apresiasi dan ketrampilan (Agus Suprijono, 2009:5). Wina Sanjaya (2010:257) mendefinisikan hasil belajar yaitu sesuatu yang diperoleh siswa sebagai hasil dari upaya yang telah dilakukan sehingga terjadi perubahan perilaku yang bersangkutan baik perilaku dalam bidang kognitif, afektif dan psikomotorik atau di dalam kurikulum 2013 kompetensi pengetahuan, kompetensi sikap dan kompetensi keterampilan. Berdasarkan pengertian di atas, hasil belajar adalah kemampuan yang mencakup aspek kognitif, afektif dan psikomotorik yang dimiliki siswa setelah mengikuti kegiatan belajar dalam proses pembelajaran. Dalam penelitian ini, hasil belajar yang diukur adalah aspek kognitif atau pengetahuan.

\section{METODE PENELITIAN Jenis Penelitian}

Jenis penelitian ini adalah Penelitian Tindakan Kelas (PTK), penelitian ini dilaksanakan dengan menggunakan e-Learning schoology yakni di kelas VIII A di SMP Kristen 2 Salatiga Tahun Pelajaran 2019/2020 yang berjumlah 21 peserta didik. Pelaksanaan penelitian dilakukan sebelum Corona (Covid-19) untuk mengetahui hasil belajar awal peserta didik dan selama Corona (Covid-19) dimana proses pembelajaran tatap muka di kelas tidak dapat dilakukan. 


\section{Tempat, Waktu dan Subjek Penelitian}

Penelitian ini dilaksanakan di SMP Kristen 2 Salatiga pada bulan Februari sampai April 2020. Subjek dalam penelitian ini adalah siswa kelas VIII A di SMP Kristen 2 Salatiga Tahun Pelajaran 2019/2020 yang berjumlah 21 peserta.

\section{Rancangan Penelitian}

Parameter penelitian ini adalah hasil belajar siswa sebesar $80 \%$. Selanjutnya untuk menilai hasil belajar yang terjadi pada siswa diberikan soal berbentuk pilihan ganda dengan nilai kuder richardson 20 sebedsar 0,80 . Dengan demikian instrumen yang digunakan dalam kajian ini adalah berkualitas dan baik. Analisis data dilakukan secara deskritif. Penelitian ini menggunakan rancangan penelitian tidakan kelas (classroom action research) yang dilaksanakan dalam dua siklus. Penelitian tindakan kelas ini dilaksanakan dengan melalui empat tahapan untuk masing-masing siklus, yaitu tahap perencanaan, pelaksanaan, pengamatan, dan refleksi.

\section{Teknik Pengumpulan Data}

Teknik pengumpulan data yang digunakan dalam penelitian ini adalah teknik dokumentasi untuk mengetahui kondisi awal siswa. Dan nilai yang digunakan untuk data didapat dari daftar nilai ulangan harian pertama setelah menyelesaikan materi sifat dan bentuk interaksi social budaya dalam pembangunan serta fungsi dan peran keragaman social budaya dalam pembangunan.

Sedangkan dalam melaksanakan tindakan pada penelitian ini, peneliti mengadakan tes/evaluasi terhadap hasil belajar siswa (postest) di setiap siklus dan melakukan observasi/pengamatan terhadap aktivitas peserta didik selama kegiatan belajar mengajar berlangsung.

\section{Teknik Analisis Data}

Analisa data dilakukan dengan cara menganalisis hasil belajar dengan analisa deskripstif komparatif yaitu membandingkan nilai ulangan harian baik pada kondisi awal, Siklus satu, maupun siklus dua.

\section{HASIL PENELITIAN DAN PEMBAHASAN Hasil Penelitian Pra Siklus}

Berikut dijelaskan hasil penelitian mengenai hasil belajar yang diperoleh peserta didik kelas VIII A SMP Kristen 2 Salatiga dibagi menjadi 3 yaitu Pra Siklus, Siklus I dan Siklus II, hal tersebut dijelaskan sebagai berikut.

Berikut disajikan tabel hasil belajar Pra Siklus yang diperoleh dari nilai Ulangan Harian sebelumnya.

Tabel 1. Tabel Ketuntasan Pra Siklus

\begin{tabular}{|l|c|c|c|c|}
\hline & Tuntas & $\begin{array}{c}\text { Tidak } \\
\text { Tuntas }\end{array}$ & Rata-Rata & Prosentase \\
\hline Pra siklus & 5 & 17 & 59,3 & $22,7 \%$ \\
\hline
\end{tabular}

Sumber : Hasil Penelitian, diolah (2020) 
Selanjutnya, disajikan grafik hasil belajar Pra Siklus yang diperoleh dari nilai Ulangan Harian sebelumnya.

Gambar 1. Grafik Hasil Belajar Siswa pada Pra Siklus

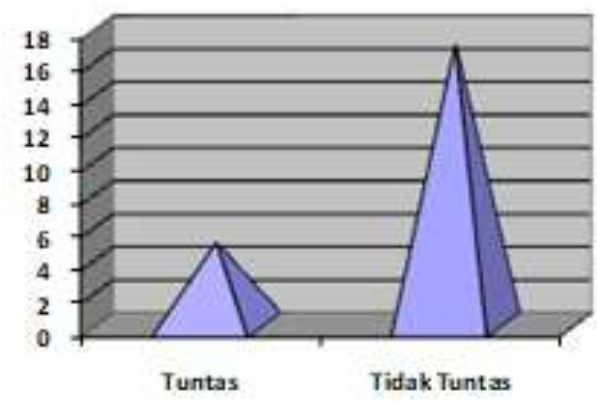

Sumber : Hasil Penelitian, diolah (2020)

Berdasarkan hasil nilai Ulangan Harian tersebut peserta didik menunjukkan bahwa ketuntasan hasil belajar kognitif atau pengetahuan dengan KKM (Kriteria Ketuntasan Minimal) adalah 75 yang dicapai pada pra siklus sebanyak 5 peserta didik dengan prosentase $22,7 \%$ dengan nilai rata-rata kelas yang diperoleh mencapai 59,3. Dari hasil tersebut mengindikasikan bahwa dalam proses pembelajaran yang sedang berlangsung saat itu belum berhasil, dikarenakan ketuntasan hasil belajar peserta didik belum mencapai indikator yang diharapkan.

\section{Siklus I}

Hasil belajar aspek kognitif atau pengetahuan diperoleh melalui ujian tertulis, dimana pelaksanaan ujian tertulis dengan aplikasi schoology dilaksanakan pada pertemuan setelah pelaksanaan diskusi tugas diskusi online. Kegiatan ini dilakukan untuk mengetahui sampai dimana materi peserta didik pada pelajaran. Berikut hasil belajar peserta didik aspek kogntif atau pengetahuan kelas VII A SMP Kristen 2 Salatiga, dengan diperoleh hasil dalam tabel dan grafik sebagai berikut.

Tabel 2. Tabel Ketuntasan Siklus I

\begin{tabular}{|l|c|c|c|c|}
\hline & Tuntas & $\begin{array}{c}\text { Tidak } \\
\text { Tuntas }\end{array}$ & Rata-Rata & Prosentase \\
\hline Siklus I & 15 & 7 & 76,3 & $68,1 \%$ \\
\hline
\end{tabular}

Sumber : Hasil Penelitian, diolah (2020)

Gambar 2. Grafik Hasil Belajar Siswa pada Siklus I

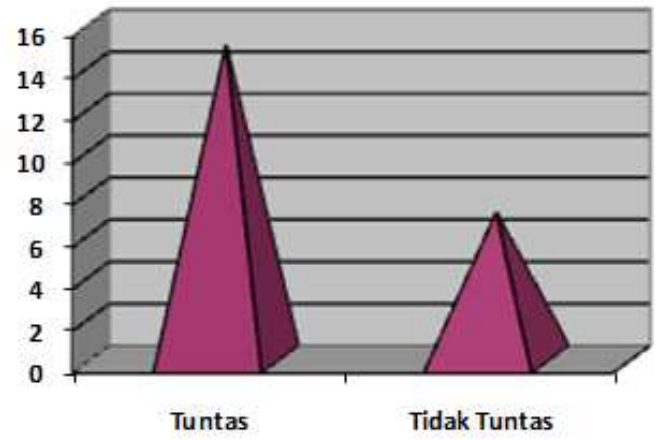

Sumber : Hasil Penelitian, diolah (2020) 
Berdasarkan hasil belajar peserta didik menunjukkan bahawa ketuntasan hasil belajar dengan KKM (Kriteria Ketuntasan Minimal) adalah 75 yang dicapai pada siklus I sebanyak 15 peserta didik dengan prosentase $68,1 \%$ dengan nilai rata-rata kelas yang diperoleh peserta didik mencapai 76,3. Dari hasil tersebut mengindikasikan bahwa dalam proses pembelajaran yang sedang berlangsung belum berhasil, sebab ketuntasan hasil belajar peserta didik belum mencapai indikator yang diharapkan. Maka akan dilakukan siklus II.

\section{Siklus II}

Hasil belajar aspek kognitif atau pengetahuan diperoleh hasil penilaian online lewat aplikasi schoology yang nilainya langsung masuk kea kun guru, pelaksanaan penilaian tersebut masih sama dengan pelaksanaan siklus I. Kegiatan ini dilakukan untuk mengetahui sampai dimana materi dan pengetahuan peserta didik saat pembelajaran. Berikut hasil belajar peserta didik siklus II.

Tabel 3. Tabel Ketuntasan Siklus II

\begin{tabular}{|l|c|c|c|c|}
\hline & Tuntas & $\begin{array}{c}\text { Tidak } \\
\text { Tuntas }\end{array}$ & Rata-Rata & Prosentase \\
\hline Siklus II & 22 & 0 & 88,5 & $100 \%$ \\
\hline
\end{tabular}

Sumber : Hasil Penelitian, diolah (2020)

\section{Gambar 3. Grafik Hasil Belajar Siswa pada Siklus II}

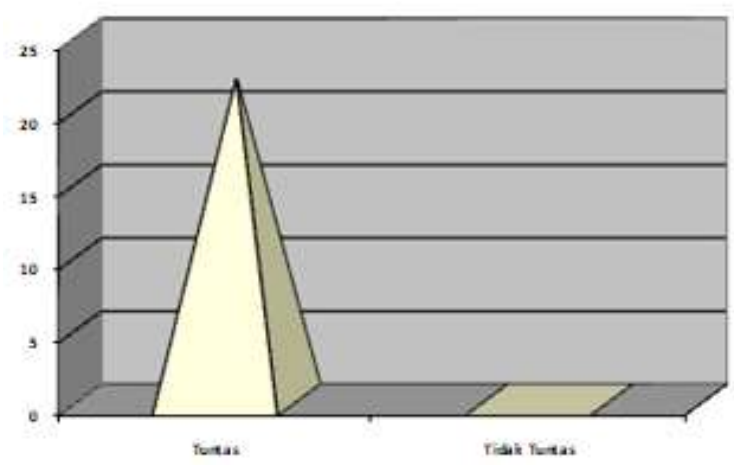

Sumber : Hasil Penelitian, diolah (2020)

Berdasarkan hasil penilaian peserta didik menunjukkan bahwa ketuntasan hasil belajar dengan KKM (Kriteria Ketuntasan Minimal) adalah 75 yang dicapai pada siklus II sebanyak 22 peserta didik dengan prosentase $100 \%$ dengan nilai rata-rata kelas yang diperoleh peserta didik mencapai 88,5. Dari hasil tersebut mengindikasikan bahwa dalam proses yang berlangsung pada siklus II sudah berhasil, sebab ketuntasan hasil belajar peserta didik sudah mencapai indikator yang diharapkan atau semua peserta didik telah tuntas dalam pembelajaran.

\section{Pembahasan}

Selanjutnya, pembahasan mengenai tahap perencanaan, pelaksanaan, pengamatan dan refleksi akan dijelaskan sebagai berikut.

\section{Perencanaan}

Penelitian dilakukan dengan cara mempersiapkan bahan ajar, soal latihan dan bahan diskusi yang akan di upload ke dalam aplikasi e-Learning 
Quizizz. Pada tahap perencanaan ini melalui sosialisasi siswa sudah dijelaskan bahwa proses pembelajaran e-Learning schoology tidak dilaksanakan di kelas karena tujuan pembelajaran ini untuk mengatasi jam tatap muka yang tidak dapat dilaksanakan karena siswa selalu libur sekolah akibat Corona (Covid-19). Siswa diminta untuk mempersiapkan fasilitas yang mendukung kelancaran pembelajaran ini, seperti ketersediaan paket internet, hp android, dan lain-lain.

2. Pelaksanaan

Pelaksanaan tindakan kelas ini berbeda dengan penelitian tindakan kelas yang biasa dilakukan. Pelaksanaan tindakan pada penelitian ini dilakukan melalui pembelajaran e-Learning Quizizz yang dilaksanakan siswa di tempatnya masing. Guru mempersiapkan materi dan soal yang sudah diupload di Quizizz dan meminta siswa mengajukan pertanyaan terhadap materi yang tidak mereka pahami. Siswa dapat melakukan share materi sesama mereka, atau share bersama guru. Guru memberi kesempatan kepada siswa terlebih dahulu untuk mengemukakan pendapat di kotak diskusi, guru akan memberikan konfirmasi tentang pendapat siswa di forum diskusi setelah beberapa siswa memberikan pendapat. Tujuan penggunaan e-Learning Quizizz ini adalah untuk memotivasi siswa agar tetap semangat belajar dalam kondisi libur akibat Corona (Covid19), dan yang paling penting adalah siswa tidak ketinggalan materi ajar akibat libur yang terlalu lama. Melalui pembelajaran e-Learning Quizizz diharapkan proses pembelajaran tetap terlaksana walaupun tidak dilakukan dengan tatap muka seperti biasanya. Pelaksanaan tindakan yang diberikan melalui dunia maya mewujudkan proses pembelajaran secara nyata yang dilakukan siswa.

3. Pengamatan

Pengamatan terhadap penelitian tindakan kelas pembelajaran e-Learning Quizizz dapat dilakukan dengan melihat partisipasi siswa saat login di aplikasi e-Learning Quizizz. Adanya aplikasi absensi sebagai fitur pelengkap pada elearning schoology memudahkan guru untuk melihat keikutsertaan siswa dalam proses pembelajaran yang dilakukan di dunia maya. Siswa-siswa yang aktif dalam kotak diskusi juga terlihat, dan hal ini memudahkan bagi guru untuk memantau siswa siswa yang tidak pernah ikut berpartisipasi dalam proses tersebut. Awal pelaksanaan masih banyak siswa yang tidak terlibat aktif dalam kotak diskusi, mereka hanya login dan melihat diskusi dari belakang layar saja. Berdasarkan hasil pra siklus, siklus I dan siklus II, diperoleh hasil sebagai berikut.

Tabel 4. Perbandingan Ketuntasan Hasil Belajar Siswa Tiap Siklus

\begin{tabular}{|l|c|c|c|c|}
\hline & Tuntas & $\begin{array}{c}\text { Tidak } \\
\text { Tuntas }\end{array}$ & Rata-Rata & Prosentase \\
\hline Pra siklus & 5 & 17 & 59,3 & $22,7 \%$ \\
\hline Siklus I & 15 & 7 & 76,3 & $68,1 \%$ \\
\hline Siklus II & 22 & 0 & 88,5 & $100 \%$ \\
\hline
\end{tabular}

Sumber : Hasil Penelitian, diolah (2020)

Dari hasil di atas, menunjukkan kenaikan dari hasil pra siklus, siklus I dan siklus II yang mempunyai arti adanya peningkatan hasil belajar dengan menggunakan quizizz. Hasil kenaikan prosentase pra siklus, siklus I dan siklus II dapat dilihat pada grafik berikut. 


\section{Gambar 4. Grafik Perbandingan Ketuntasan Hasil Belajar Siswa Tiap Siklus}

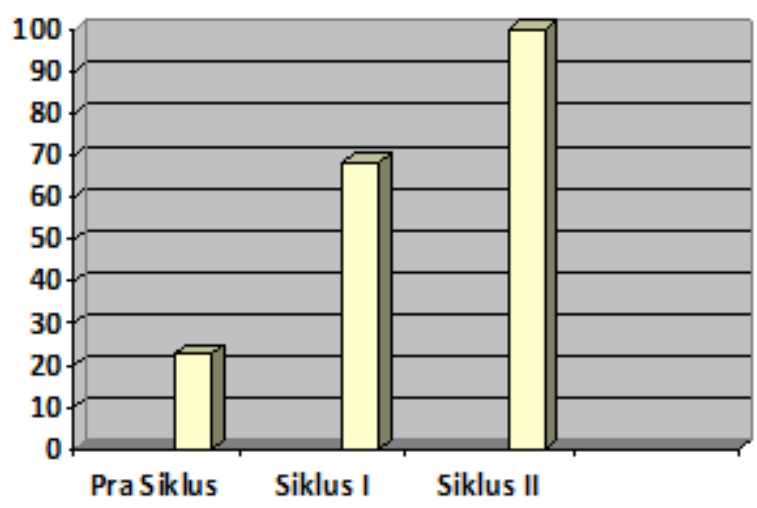

Sumber : Hasil Penelitian, diolah (2020)

\section{Refleksi}

Refleksi awal pada penelitian tindakan kelas secara e-Learning Quizizz. penulis mendapati ada beberapa kekurangan yang harus diperbaiki. Misalnya pada penetapan waktu yang diberikan kepada siswa, semula penulis hanya memberikan intruksi yang akan keluar lewat notifikasi HP masing-masing siswa tanpa memberikan batasan waktu untuk satu konsep materi. Hal ini mengakibatkan siswa lalai untuk membuka kotak diskusi. Untuk latihan soal, waktu yang diberikan terlalu lama tanpa time limit. Hal ini memicu siswa untuk melakukan kerjasama dan negosiasi diantara sesama mereka. Hasil refleksi pertama ini penulis gunakan untuk perbaikan pada proses pembelajaran e-Learning berikutya. Penulis mulai dengan memberikan batasan waktu untuk setiap fitur yang akan dilaksanakan, siswa mengikuti dengan disiplin dan seksama. Semua refleksi yang diperoleh pada tahap awal digunakan untuk perbaikan pada tahap berikutnya.

\section{KESIMPULAN DAN SARAN Kesimpulan}

Berdasarkan hasil penelitian dan pembahasan, serta analisis data yang telah diuraikan dapat disimpulkan bahwa pembelajaran online dengan aplikasi Quizizz dapat meningkatkan hasil belajar PPKn kelas VIII A SMP Kristen 2 Salatiga. Peningkatan hasil belajar peserta didik siklus 1 dan siklus 2 dapat dilihat dari Hasil belajar peserta didik aspek kognitif atau pengetahuan pada pra siklus yaitu $22,7 \%$, kemudian pada siklus 1 mencapai $68,1 \%$, selanjutnya meningkat pada siklus 2 yaitu $100 \%$ atau peserta didik mencapai batas ketuntasan semuanya.

\section{Saran}

Saran yang diberikan adalah guru hendaknya dapat memilih model pembelajaran yang cocok, guru juga harus lebih up to date dengan perkembangan teknologi yang digunakan dalam pembelajaran, Peserta didik hendaknya lebih berpartisipasi aktif dalam kegiatan diskusi tatap muka maupun diskusi online. 


\section{DAFTAR PUSTAKA}

Agus Suprijono. 2009. Cooperative Learning Teori dan Aplikasi Paikem. Yogyakarta : Pustaka Pelajar.

Fendi Rakhman. 2009. Pengembangan E-Learning Berbasis Schoology pada mata Pelajaran Teknik Elektronika. Malang.

Kunandar. 2013. Penilaian Auntentik (Penilaian Hasil Belajar Peserta Didik Berdasarkan Kurikulum 2013). Jakarta: PT Raja Grafindo Persada.

Leony Sanga Lamsari Purba. 2019. Peningkatan Konsentrasi Belajar Mahasiswa Melalui Pemanfaatan Evaluasi Pembelajaran Quizizz Pada Mata Kuliah Kimia Fisika I. JDP Volume 12, Nomor 1, April 2019 : 29-39.

Ramadhan Prasetya Wibawa, dkk. 2019. Smartphone Based Application "quizizz" as a Learning Media. Dinamika Pendidikan Volume 14 Nomor 2 2019:244253.

Wina Sanjaya. 2010. Strategi Pembelajaran Beroientasi Standar Proses Pendidikan. Jakarta: Kencana. 